KIMMEL, H. D., \& GREENE, W. A. Disinhibition in GSR conditioning as a function of the number of CS-UCS trials and temporal location of the novel stimulus. Journal of Experimental Psychology, 1964, 68, 567-572.

KOEPKE, J E., \& PRIBRAM K. H. Habituation of GSR as a function of stimulus duration and spontaneous activity Joumal of Comparative \& Physiological Psychology. 1966, 61. $442-448$

ZAHN P.T \& ROSENTHAL, D. Simple reaction time as a function of the relative frequency of the preparatory interval. Journal of Experimental Psychology, $1966,72,15-19$.

\title{
An analysis of response patterns for conditional reasoning schemes
}

\author{
JAMES J. ROBERGE \\ Temple University, Philadelphia, Pa. 19122
}

One hundred and ten college Ss assessed the truth of the conclusions for 40 conditional reasoning items. These items varied according to principles of inference and validity status. The results indicated some interesting intra- and interrule variations in response patterns.

A number of investigators (e.g., Ennis, 1970; Ennis \& Paulus, 1965; Gardiner, 1965; Hill, 1961; Howell, 1965; Martens, 1967; Matalon, 1962; Miller, 1968; O'Brien \& Shapiro, 1968 Paulus, 1967; Roberge, 1970; Roberge \& Paulus, 1971; Shapiro \& O'Brien, $1970 \mathrm{a}, \mathrm{b} ;$ Suppes, 1965) have examined children's comprehension of conditional reasoning schemes. However, there has been a dearth of similar research with adults. More precisely, most of the research on the propositional reasoning abilities of adults (e.g., Johnson-Laird \& Tagart, 1969; Johnson-Laird \& Wason, 1970 Wason, 1964, 1966, 1968, 1969a, b; Wason \& Johnson-Laird, 1970) has focused on tasks in which Ss had to select (or classify) stimuli which would make conditional sentences (or rules) true or false and on therapeutic procedures designed to reduce $\mathrm{Ss}^{\prime}$ tendencies to make fallacious inferences, rather than on tasks in which Ss had to assess the truth of the conclusions for conditional reasoning schemes. Furthermore. those studies which have employed tasks of the latter type have been limited to valid rules of inference (e.g., Stewart, 1961).

Thus, the aim of the present investigation was to measure adults' abilities to assess the truth of the conclusions for logical arguments embodying one of five basic principles of conditional reasoning. These were: (1) $P \supset Q, P, \therefore Q$ (modus ponens) (2) $\mathrm{P} \supset \mathrm{Q}, \mathrm{Q}, \therefore \mathrm{P}$ (affirmation of the consequent or conversion); (3) $\mathrm{P} \supset \mathrm{Q}$, $\bar{P}, \therefore \bar{Q}$ (denial of the antecedent or inversion); (4) $\mathrm{P} \supset \mathrm{Q}, \overline{\mathrm{Q}}, \therefore \overline{\mathrm{P}}$ (modus tollens or contraposition); (5) $\mathrm{P} \supset \mathrm{Q}$, $\mathrm{Q} \supset \mathrm{R}, \therefore \mathrm{P} \supset \mathbf{R}$ (transitivity). Detailed information about adults' abilities to reason with these conditional reasoning schemes is essential for the formulation of a comprehensive theory of cognitive development.

\section{SUBJECTS}

The Ss were 110 graduate students in educational psychology at Temple University.

\section{MATERIALS}

A 40-item conditional reasoning test was constructed by the $\mathrm{E}$. These 40 items represent the eight possible arrangements (according to the presence or absence of negation) of the terms in the major premise and the conclusion for the five basic principles of conditional reasoning. A complete listing of the premises, conclusions, and validity statuses of the items is presented in Table 1. Each item contained two premises and a conclusion, e.g., suppose you know that

If there is a $Q$, then there is an $R$.

There is a $Q$.

then would this be true?

There is an $R$.

The possible responses which the Ss could make were "YES," "NO," and "MAYBE." The meanings of the possible answers were explained to the Ss as follows: "YES-it must be true; NO-it can't be true; MAYBE-it may be true or it may not be true. You weren't told enough to be certain whether it is 'YES' or 'NO.' "'

To avoid extraneous influences on responses, premises and conclusions involving capital letters $(P, Q, R$, and $\mathrm{S})$ were used. Moreover, the order of presentation of the 40 items was randomized both within and across the principles of inference, with the additional restriction that no two items for the same principle appear consecutively.

RESULTS AND DISCUSSION

The structural characteristics of each item and its validity status are shown in Table 1. In addition, the percentages of Ss choosing ratch alternative, the keyed alternative, and the discrimination index (Johnson, 1951 ) are presented.

The mean difficulties for the five principles were $.95, .48, .69, .45$, and .86 , respectively. In general, the relative difficulties of the various principles confirmed expectations based on extrapolation from the findings of previous studies with adolescents (e.g., Ennis \& Paulus, 1965; Gardiner, 1965; Howell, 1965; Miller, 1968; Roberge, 1970). Moreover, the relative difficulties of Principles 2 and 3 supported Wason's (1964) finding that, for adults, "the affirmation of the consequent is a much more deceptive fallacy than the denial of the antecedent [p. 32].'

The mean discrimination indices for the five principles were $.07, .61, .49$, .08 , and .24 , respectively. Thus, the items for the fallacies, particularly Principle 2 (conversion), best discriminated between the groups of high- (upper 27\%) and low- (lower $27 \%$ ) scoring Ss formed on the basis of total test score. On the other hand, the easiness of the items for Principles 1 (modus ponens) and 5 (transitivity) had a debilitating effect on the corresponding discrimination indices for these items. Furthermore, al though the items for Principle 4 (contraposition) had an average difficulty of .45 , the discrimination indices for these items were surprisingly low. An analysis of the response patterns for the latter items revealed that the erroneous response MAYBE was selected by many Ss, and that it was equally attractive to both high- and low-scoring Ss.

Further examination of the response patterns revealed that for Principle 2 items the preferred error was YES when the conclusion and the antecedent of the major premise were congruent and NO when they were not congruent. However, for Principle 3 items the preferred error was YES when the conclusion and the consequent of the major premise were not congruent and NO when they were congruent. These patterns of error preference for the fallacies were concordant with those reported in earlier studies with adolescents (e.g. Gardiner, 1965; Howell, 1965; Martens, 1967; Miller, 1968).

Finally, the response patterns for Principle 4 items can be partially explained by Wason's (1966) hypothesis, and the empirical findings of Johnson-Laird \& Tagart (1969), with respect to $\mathrm{Ss}^{\prime}$ tendencies to classify a conditional sentence of the form "If $P$, then $Q$ " as irrelevant in any situation that falsifies its antecedent. Specifically, approximately $20 \%$ more Ss selected 
Summary of the Item Analysis Data

\begin{tabular}{|c|c|c|c|c|c|c|c|c|c|}
\hline Item & $\begin{array}{l}\text { Prin- } \\
\text { ciple }\end{array}$ & $\begin{array}{l}\text { Major } \\
\text { Premise }\end{array}$ & $\begin{array}{l}\text { Minor } \\
\text { Premise }\end{array}$ & $\begin{array}{c}\text { Conclu- } \\
\text { sion }\end{array}$ & Valid & Yes & No & Maybe & D \\
\hline $\begin{array}{r}3 \\
38 \\
10 \\
24 \\
27 \\
13 \\
16 \\
32\end{array}$ & $\begin{array}{l}1 \\
1 \\
1 \\
1 \\
1 \\
1 \\
1 \\
1\end{array}$ & $\begin{array}{l}\mathbf{P} \supset \mathbf{Q} \\
\mathbf{P} \supset \mathbf{Q} \\
\overline{\mathbf{P}} \supset \mathbf{Q} \\
\overline{\mathbf{P}} \supset \mathbf{Q} \\
\mathbf{P} \supset \frac{\mathbf{Q}}{P} \\
\mathbf{P} \supset \frac{\mathbf{Q}}{\overline{\mathbf{P}}} \overline{\mathbf{Q}} \\
\overline{\mathbf{P}} \supset \overline{\mathbf{Q}}\end{array}$ & $\begin{array}{l}P \\
\frac{P}{P} \\
\frac{P}{P} \\
\frac{P}{P} \\
\frac{P}{P}\end{array}$ & $\begin{array}{l}\frac{Q}{Q} \\
\frac{Q}{Q} \\
\frac{Q}{Q} \\
\frac{Q}{Q}\end{array}$ & $\begin{array}{l}\text { Yes } \\
\text { Yes } \\
\text { Yes } \\
\text { Yes } \\
\text { Yes } \\
\text { Yes } \\
\text { Yes } \\
\text { Yes }\end{array}$ & $\begin{array}{c}97+ \\
1 \\
93+ \\
6 \\
3 \\
99+ \\
4 \\
97+\end{array}$ & $\begin{array}{c}0 \\
97+ \\
3 \\
91+ \\
95+ \\
1 \\
94+ \\
2\end{array}$ & $\begin{array}{l}3 \\
2 \\
5 \\
3 \\
3 \\
0 \\
3 \\
1\end{array}$ & $\begin{array}{r}.06 \\
.03 \\
.16 \\
.13 \\
.13 \\
-.03 \\
.00 \\
.06\end{array}$ \\
\hline $\begin{array}{r}8 \\
5 \\
29 \\
39 \\
21 \\
18 \\
11 \\
35\end{array}$ & $\begin{array}{l}2 \\
2 \\
2 \\
2 \\
2 \\
2 \\
2 \\
2\end{array}$ & $\begin{array}{l}\mathbf{P} \supset \mathbf{Q} \\
\mathbf{P} \supset \mathbf{Q} \\
\overline{\mathbf{P}} \supset \mathbf{Q} \\
\overline{\mathbf{P}} \supset \mathbf{Q} \\
\mathbf{P} \supset \overline{\mathbf{Q}} \\
\mathbf{P} \supset \overline{\mathbf{Q}} \\
\overline{\mathbf{P}} \supset \overline{\mathbf{Q}} \\
\overline{\mathbf{P}} \supset \overline{\mathbf{Q}}\end{array}$ & $\begin{array}{l}\mathbf{Q} \\
\mathbf{Q} \\
\mathbf{Q} \\
\frac{\mathbf{Q}}{\bar{Q}} \\
\frac{\bar{Q}}{\mathbf{Q}} \\
\frac{\mathbf{Q}}{\mathbf{Q}}\end{array}$ & $\begin{array}{l}\frac{\mathbf{P}}{\mathrm{P}} \\
\frac{\mathrm{P}}{\mathbf{P}} \\
\frac{\mathbf{P}}{\mathbf{P}} \\
\frac{\mathbf{P}}{\mathbf{P}}\end{array}$ & $\begin{array}{l}\text { No } \\
\text { No } \\
\text { No } \\
\text { No } \\
\text { No } \\
\text { No } \\
\text { No } \\
\text { No }\end{array}$ & $\begin{array}{r}45 \\
1 \\
1 \\
\mathbf{5 9} \\
53 \\
5 \\
1 \\
\mathbf{4 5}\end{array}$ & $\begin{array}{r}0 \\
50 \\
60 \\
1 \\
0 \\
43 \\
53 \\
2\end{array}$ & $\begin{array}{l}55+ \\
49+ \\
39+ \\
40+ \\
47+ \\
53+ \\
46+ \\
53+\end{array}$ & $\begin{array}{l}.72 \\
.54 \\
.57 \\
.51 \\
.63 \\
.69 \\
.66 \\
.57\end{array}$ \\
\hline $\begin{array}{r}14 \\
1 \\
25 \\
28 \\
34 \\
7 \\
40 \\
20\end{array}$ & $\begin{array}{l}3 \\
\mathbf{3} \\
\mathbf{3} \\
\mathbf{3} \\
\mathbf{3} \\
\mathbf{3} \\
\mathbf{3} \\
\mathbf{3}\end{array}$ & $\begin{array}{l}\mathbf{P} \supset \mathbf{Q} \\
\mathbf{P} \supset \mathbf{Q} \\
\overline{\mathbf{P}} \supset \mathbf{Q} \\
\overline{\mathbf{P}} \supset \mathbf{Q} \\
\mathbf{P} \supset \overline{\mathbf{Q}} \\
\mathbf{P} \supset \overline{\mathbf{Q}} \\
\overline{\mathbf{P}} \supset \overline{\mathbf{Q}} \\
\overline{\mathbf{P}} \supset \overline{\mathbf{Q}}\end{array}$ & $\begin{array}{l}\bar{P} \\
\bar{P} \\
P \\
\frac{P}{P} \\
\bar{P} \\
P \\
P\end{array}$ & $\begin{array}{l}\frac{Q}{Q} \\
\frac{Q}{\bar{Q}} \\
\frac{Q}{\bar{Q}} \\
\frac{Q}{Q}\end{array}$ & $\begin{array}{l}\text { No } \\
\text { No } \\
\text { No } \\
\text { No } \\
\text { No } \\
\text { No } \\
\text { No } \\
\text { No }\end{array}$ & $\begin{array}{r}1 \\
28 \\
2 \\
26 \\
9 \\
10 \\
9 \\
7\end{array}$ & $\begin{array}{r}48 \\
5 \\
40 \\
3 \\
4 \\
25 \\
3 \\
32\end{array}$ & $\begin{array}{l}51+ \\
67+ \\
58+ \\
71+ \\
87+ \\
65+ \\
88+ \\
61+\end{array}$ & $\begin{array}{l}.72 \\
.50 \\
.53 \\
.47 \\
.31 \\
.57 \\
.19 \\
.60\end{array}$ \\
\hline $\begin{array}{r}36 \\
22 \\
31 \\
12 \\
6 \\
17 \\
4 \\
26\end{array}$ & $\begin{array}{l}4 \\
4 \\
4 \\
4 \\
4 \\
4 \\
4 \\
4\end{array}$ & $\begin{array}{l}\mathbf{P} \supset \mathbf{Q} \\
\mathbf{P} \supset \mathbf{Q} \\
\overline{\mathbf{P}} \supset \mathbf{Q} \\
\overline{\mathbf{P}} \supset \mathbf{Q} \\
\mathbf{P} \supset \overline{\mathbf{Q}} \\
\mathbf{P} \supset \overline{\mathbf{Q}} \\
\overline{\mathbf{P}} \supset \overline{\mathbf{Q}} \\
\overline{\mathbf{P}} \supset \overline{\mathbf{Q}}\end{array}$ & $\begin{array}{l}\overline{\mathbf{Q}} \\
\overline{\mathbf{Q}} \\
\overline{\mathbf{Q}} \\
\overline{\mathbf{Q}} \\
\mathbf{Q} \\
\mathbf{Q} \\
\mathbf{Q} \\
\mathbf{Q}\end{array}$ & $\begin{array}{l}\frac{P}{P} \\
\frac{P}{P} \\
\frac{P}{P} \\
\frac{P}{P}\end{array}$ & $\begin{array}{l}\text { Yes } \\
\text { Yes } \\
\text { Yes } \\
\text { Yes } \\
\text { Yes } \\
\text { Yes } \\
\text { Yes } \\
\text { Yes }\end{array}$ & $\begin{array}{c}2 \\
45+ \\
15+ \\
4 \\
4 \\
46+ \\
30+ \\
7\end{array}$ & $\begin{array}{c}63+ \\
5 \\
5 \\
44+ \\
68+ \\
4 \\
6 \\
52+\end{array}$ & $\begin{array}{l}35 \\
50 \\
80 \\
53 \\
28 \\
50 \\
64 \\
41\end{array}$ & $\begin{array}{r}.17 \\
.05 \\
-.10 \\
.14 \\
.10 \\
.20 \\
-.04 \\
.14\end{array}$ \\
\hline $\begin{array}{r}9 \\
15 \\
30 \\
37 \\
33 \\
23 \\
19 \\
2\end{array}$ & $\begin{array}{l}\mathbf{5} \\
\mathbf{5} \\
\mathbf{5} \\
\mathbf{5} \\
\mathbf{5} \\
5 \\
\mathbf{5} \\
\mathbf{5}\end{array}$ & $\begin{array}{l}\mathbf{P} \supset \mathbf{Q} \\
\mathbf{P} \supset \mathbf{Q} \\
\overline{\mathbf{P}} \supset \mathbf{Q} \\
\overline{\mathbf{P}} \supset \mathbf{Q} \\
\mathbf{P} \supset \overline{\mathbf{Q}} \\
\mathbf{P} \supset \frac{\mathbf{Q}}{\mathbf{P}} \supset \frac{\mathbf{Q}}{\mathbf{P}} \supset \frac{\mathbf{Q}}{}\end{array}$ & $\begin{array}{l}\mathbf{Q} \supset \mathbf{R} \\
\mathbf{Q} \supset \mathbf{R} \\
\mathbf{Q} \supset \mathbf{R} \\
\mathbf{Q} \supset \mathbf{R} \\
\overline{\mathbf{Q}} \supset \mathbf{R} \\
\overline{\mathbf{Q}} \supset \mathbf{R} \\
\overline{\mathbf{Q}} \supset \mathbf{R} \\
\mathbf{Q} \supset \mathbf{R}\end{array}$ & $\begin{array}{l}\mathbf{P} \supset \mathbf{R} \\
\mathbf{P} \supset \overline{\mathbf{R}} \\
\overline{\mathbf{P}} \supset \mathbf{R} \\
\overline{\mathbf{P}} \supset \overline{\mathbf{R}} \\
\mathbf{P} \supset \mathbf{R} \\
\mathbf{P} \supset \overline{\mathbf{R}} \\
\overline{\mathbf{P}} \supset \mathbf{R} \\
\overline{\mathbf{P}} \supset \overline{\mathbf{R}}\end{array}$ & $\begin{array}{l}\text { Yes } \\
\text { Yes } \\
\text { Yes } \\
\text { Yes } \\
\text { Yes } \\
\text { Yes } \\
\text { Yes } \\
\text { Yes }\end{array}$ & $\begin{array}{c}93+ \\
0 \\
89+ \\
2 \\
92+ \\
6 \\
85+ \\
25\end{array}$ & $\begin{array}{c}0 \\
95+ \\
3 \\
90+ \\
3 \\
80+ \\
5 \\
66+\end{array}$ & $\begin{array}{r}7 \\
5 \\
8 \\
8 \\
5 \\
14 \\
10 \\
9\end{array}$ & $\begin{array}{l}.10 \\
.13 \\
.22 \\
.22 \\
.19 \\
.41 \\
.28 \\
.35\end{array}$ \\
\hline
\end{tabular}

Note $-\vec{P}=$ not $P ;+$ indicates the keyed alternative.

the MAYBE response for the subset of Principle 4 items in which the conclusion falsified (negated) the antecedent of the major premise, i.e., Items $4,17,22$, and 31 .

In summary, the results of this study shed new light on the ontogenesis of comprehension of conditional reasoning schemes. For example, the demonstrated inability of many of the Ss to correctly evaluate the conclusions of logical arguments embodying the principles of conversion, inversion, and contraposition suggests that many intelligent adults have not attained the level of formal operations (Inheldei \& Piaget, 1958) in the development $c^{*}$ their propositional reasoning ability. Considered in conjunction with the findings reported by Wason (1968) and Johnson-Laird \& Tagart (1969), these results raise doubt as to the accuracy of Piaget's description of cognitive development during adulthood.
IOHNSON, A. P. Notes on a suggested index of item validity: The U-L index. Journal of Educational Psychology, 1951, 42, 499-504.

JOHNSON-LAIRD, P. N., \& TAGART, J. How implication is understood. American Journal of Psychology, 1969, 82, 367-373.

JOHNSON-LAIRD, P N, \& WASON, P. C. Insight into a logical relation. Quarterly Journal of Experimental Psychology, 1970, 22, 49-61.

MARTENS, M. A. Use of selected rules of logical inference and of logical fallacies by high school seniors. (Doctoral dissertation, University of Wisconsin) Ann Arbor, Mich: University Microfilms, 1967. No. 67-16,980.

MATALON, B. Etude genetique de l'implication. In J. Piaget (Ed.). Etudes d'epistemologie genetique: XVI. Implication, formolisation et logique naturelle. Paris: Presses Universitaires de France, 1962. Pp. 69-95.

MILLER, W. A. The acceptance and recognition of six logical inference patterns by secondary students. (Doctoral dissertation, University of Wisconsin) Ann Arbor. Mich: University Microfilms, 1968. No. 68-13,651

O'BRIEN, T. C., \& SHAPIRO, B. J. The development of logical thinking in children. American Educational Research Journal, 1968, 5, 531-542.

PAULUS, D. H. A study of children's abilities to deduce and to judge deductions. (Doctoral dissertation. Cornell University) Ann Arbor, Mich: University Microfilms, 1967 . No. 67-16,365.

ROBERGE, J. J. A study of children's abilities to reason with basic principles of deductive reasoning. American Educational Research Journal, 1970, 7, 583-596.

ROBERGE, J. J., \& PAULUS, D. H. Developmental patterns for children's class and conditional reasoning abilities. Developmental Psychology, 1971, 4, in press.

SHAPIRO, B. J., \& O'BRIEN, T. C. An investigation of children's logic. Paper presented at the meeting of the American Educational Research Association, Minneapolis, March 1970a.

SHAPIRO, B. J., \& O'BRIEN, T. C. Logical thinking in children ages six through thirteen. Child Development, 1970b, 41, 823-829.

STEWART, D. K. Communication and logic: I. Evidence for the existence of validity patterns. Journal of General Psy chology, 1961, 64, 297-305.

SUPPES, $P$. On the behavioral foundations UPPES, P. On the behavioral foundations
of mathematical concepts. Monographs of the Society for Research in Child Development, 1965, 30, 60-96.

WASON, P. C. The effect of self-contradiction on fallacious reasoning. Quarterly Journal of Experimental Psychology, 1964, 16, 30-34.

WASON, $P$. C. Reasoning. In B. M. Foss (Ed.), New horizons in psychology. Baltimore: Penguin Books, 1966. Pp. 135-151.

WASON, P. C. Reasoning about a rule. Quarterly Journal of Experimental Psychology, 1968, 20, 273-281.

WASON, P. C. Regression in reasoning? British Journal of Psy chology, 1969a, 60. 471-480.

WASON, P. C. Structural simplicity and psychological complexity: Some thoughts on a novel problem. Bulletin of the British Psychological Society, 1969b, 22 , 281-284.

WASON, P. C., \& JOHNSON-LAIRD, P. N. $A$ conflict between selecting and evaluating information in an inferential task. British Journal of Psychology, 1970, 61. 509-515. 